\title{
21
}

\section{Dealing Fairly with the Costs to the Poor of the Global Financial Crisis}

\author{
CHRISTIAN BARRY AND MATT PETERSON*
}

It has become a commonplace that the costs of the current global financial crisis are massive. In 2009, the world's combined economies are predicted to shrink by almost $3 \%$ - the first global contraction in 60 years. Although the bulk of that decline in income is concentrated in affluent countries, developing countries other than India and China are expected to shrink by $1.6 \%{ }^{1}$

While the scope of the financial crisis has been global, the policy response to it has not been. The recent international summit convened by the UN General Assembly to address the effects of the financial crisis on developing countries is instructive in this regard. An initial draft of the summit's outcome document boldly called for a $\$ 3$ trillion 'Global Stimulus for Restructuring and Survival.' ${ }^{2}$ However, the notion of a global stimulus ultimately disappeared completely; the world's governments promised, rather vaguely, to 'work in solidarity on a vigorous, coordinated and comprehensive global response to the crisis in accordance with our respective abilities and responsibilities'. How this is to be achieved is not spelled out, beyond that 'each country has primary responsibility for its own economic and social development. ${ }^{3}$

Given the failure to agree on a collective response, national policymakers need guidance on how the costs of responding to the crisis should be allocated. In this essay, we will sketch out some possible answers to the question of how to address one particular type of cost that the crisis is engendering: severe shortfalls that persons are likely suffer in their health, civic status or standard of living relative to the ordinary needs and requirements—food, drink, shelter, minimal health protection—of human beings. ${ }^{4}$ Of course,

\footnotetext{
* Christian Barry (Senior Research Fellow, Centre for Applied Philosophy \& Public Ethics (CAPPE), Australian National University) and Matt Peterson (Postgraduate Fellow, Yale University).

${ }^{1}$ India and China should grow, but at a considerably slower pace. World Bank, 'Global Development Finance: Charting a Global Recovery: I: Review, Analysis and Outlook' (Washington, DC2009) xi, available at http://siteresources.worldbank.org/INTGDF2009/Resources/gdf_combined_web.pdf (accessed on 26 August 2009).

2 President of the General Assembly, 'Draft Outcome Document for the United Nations Conference on the World Financial and Economic Crisis and Its Impact on Development' (8 May 2009), available at http://www.un.org/ga/president/63/interactive/financialcrisis/outcomedoc80509.pdf (accessed on 26 August 2009).

${ }^{3}$ United Nations, 'Outcome of the United Nations Conference on the World Financial and Economic Crisis and Its Impact on Development', A/CONF.214/3 (22 June 2009) para 10, available at http://www.un.org/ga/ search/view_doc.asp?symbol=A/CONF.214/3\&Lang=E (accessed on 26 August 2009).

${ }^{4}$ We refer to these shortfalls from a minimally adequate standard of living simply as 'severe deprivations'.
} 
there is a great deal of severe deprivation in our world that cannot in any way be attributed to this crisis. We want to ask who, morally speaking, should bear the costs of trying to alleviate or at least mitigate the additional deprivations that will be engendered by the crisis. Recent estimates suggest that these deprivations will be substantial. The International Labor Organization estimates that some 40 million people may lose their lobs in developing countries as a result of the crisis-more than twice the number of job losses expected in developed countries. ${ }^{5}$ In China alone, 20 million migrant workers have lost their jobs already. ${ }^{6}$ Per capita income in sub-Saharan Africa may decline by $20 \%{ }^{7}$ Predictably, this loss of income by the world's most vulnerable people will produce immense suffering — an additional 1.4-2.8 million infants will die over the next six years as a result of the financial crisis. ${ }^{8}$

\section{A. Choosing the Right Comparison}

Many policymakers and commentators have reached outside of the realm of finance to frame our understanding of the crisis. It has been likened to (amongst other things) the sinking of the Titanic (by Brazilian president Lula da Silva), ${ }^{9}$ a car wreck (by numerous media commentators), ${ }^{10}$ a shipwreck (by French president Nicholas Sarkozy) ${ }^{11}$ and a tsunami (by former US Federal Reserve chairman Alan Greenspan). ${ }^{12}$ Our choice of analogy is significant, since, as we argue, they each express different attitudes toward the nature of the costs and the responsibilities of the various actors involved. None of the analogies are perfect, but the first and last seem clearly to be the least apt. The world economy is (unlike the Titanic) still afloat despite the recent downturn, and (unlike a tsunami) the crisis and the costs it have engendered are clearly man-made, rather than the handiwork of Mother Nature. The same goes for the shipwreck analogy—although the

${ }^{5}$ International Labour Organization, 'Global Employment Trends: May 2009 Update' (Geneva, International Labour Office, 2009) table B2, 27, available at http://www.ilo.org/wcmsp5/groups/public/—-dgreports/ - -dcomm/documents/publication/wcms_106504.pdf (accessed on 26 August 2009).

${ }^{6}$ Chi-Chu Tschang, 'A Tough Year for China's Migrant Workers', BusinessWeek, 4 February 2009, available at http://www.businessweek.com/globalbiz/content/feb2009/gb2009024_357998.htm (accessed on 26 August 2009).

7 UNESCO press release, 'Global Crisis Hits Most Vulnerable', 3 March 2009, available at http:// portal.unesco.org/en/ev.php-URL_ID=44687\&URL_DO=DO_TOPIC\&URL_SECTION=201.html (accessed on 26 August 2009).

${ }^{8}$ World Bank, 'Swimming Against the Tide: How Developing Countries are Coping with the Global Crisis' (March 2009), available at http://www-wds.worldbank.org/.../477800WP0swimm10Box338866B01PUBLIC1.pdf (accessed on 26 August 2009), p 10.

9 D Francis, 'World Is Titanic without Paddle-Lula', National Post, 15 April 2009, available at http://network.nationalpost.com/np/blogs/francis/archive/2009/04/15/world-is-titanic-without-paddle-lula.aspx (accessed on 26 August 2009).

${ }_{10}$ Among many others, see P Thomasch, 'Zelnick: Welcome to the Emergency Room', Reuters, 4 December 2008, available at http://blogs.reuters.com/summits/2008/12/04/zelnick-welcome-to-the-emergency-room (accessed on 26 August 2009); and E Simon, 'Financial Crisis: Is It Time to Invest', Daily Telegraph, 19 September 2008, available at http://www.telegraph.co.uk/finance/newsbysector/banksandfinance/2992018/Financial-crisisis-it-time-to-invest.html (accessed on 26 August 2009).

${ }^{11}$ L Marlowe, 'Sarkozy Calls for Capitalism with a Dose of Morality', Irish Times, 26 September 2008, available at http://www.irishtimes.com/newspaper/world/2008/0926/1222374595726.html (accessed on 26 August 2009).

12 'Financial Crisis "Like a Tsunami", BBC News, 23 October 2008, available at http://news.bbc.co.uk/2/hi/ business/7687101.stm (accessed on 26 August 2009). 
movements of financial markets are often as unpredictable as the ocean, they are at least in principle subject to the controls of human agency. A car wreck, on the other hand, involves, as the crisis does, interactions between human beings using powerful vehicles that lead to significant damage. And, just as in the aftermath of a car wreck, it is sensible to ask who if anyone is at fault for its occurrence, and who should pay the damages. A car accident would involve costs to the cars and motorists involved, and perhaps also to third parties, and the question would be whether these costs should be left to fall on these people or shifted (partially or in whole) to others.

To make things more concrete, let's focus in on just one of the many ways that the financial crisis may contribute to severe deprivations-it may create a financing gap and make the debts of many countries unserviceable. ${ }^{13}$ The International Monetary Fund (IMF) projects that the poorest 38 countries will need to borrow some $\$ 216$ billion dollars to meet their national and international obligations this year. ${ }^{14}$ This figure assumes that development aid flows will remain unchanged, however, which is doubtful given the recent track record of the affluent in meeting their existing aid targets. ${ }^{15}$ The World Bank suggests that developing countries as a whole will need some $\$ 700$ billion in additional financing. ${ }^{16}$ High debt levels and financing gaps can limit the capacities of countries' governments to provide the social services necessary to ensure even a minimally adequate standard of living for their people, and to divert resources and energy from the pursuit of short- and long-term strategies that further their peoples' well-being. This effect is particularly acute in the poorest countries and is magnified by exchange rate volatility, since poor countries often borrow in foreign currencies.

In the late 1980s, economists began to caution against 'debt overhang' - the build-up of large debts, which creates a climate of permanent financial fragility in a country, leaving that country in a financial and economic slump, without domestic revenue to pay for current expenditures. Because of its financial instability, the country is deemed to be high-risk from an investment perspective. ${ }^{17}$ Creditors demand a higher interest rate on investment finance-if willing to lend at all — since many of them may have substantial outstanding debt claims on the country. ${ }^{18}$ Financial crises and the debts that often engender them can also lead the crisis countries to increased dependence on international institutions such as the IMF, which arguably limits the capabilities of their citizens to exercise meaningful control over their policies and institutions.

Suppose that some country becomes heavily indebted, and that its government can, as a result of decreased resources resulting from the crisis, service its contractually defined debt

\footnotetext{
13 This is not, of course, the only way that the crisis may produce deprivation. As consumption slows in net-importing countries like the US, the volume of international trade will decline, and high-income export-production jobs will disappear in export-oriented countries. Similarly, the flow of remittances-a critical income support for many in developing countries-will also diminish. To the extent that these sources of income are taxed, government revenues will decline, with a consequent decrease in the provision of social services. These consequences, and others, are reviewed in the World Bank's 'Swimming against the Tide' report, above n 8 .

14 International Monetary Fund, 'The Implications of the Global Financial Crisis for Low-Income Countries' (March 2009), available at http://www.imf.org/external/pubs/ft/books/2009/globalfin/globalfin.pdf (accessed on 26 August 2009), p. 34.

${ }^{15}$ V Walt, 'Why Wealthy Nations Are Stiffing Africa', Time, 12 June 2009, available at http://www.time.com/ time/business/article/0,8599,1904339,00.html (accessed on 26 August 2009).

16 World Bank, above n 8, 6 .

17 T Palley, 'Sovereign Debt Restructuring Proposals: A Comparative Look' (2003) 17(2) Ethics \& International Affairs 26.

18 Ibid.
} 
obligations only by severely cutting back on expenditures on education, health and security. Suppose further that these cutbacks will predictably lead to severe deprivations in its population. We would then be faced with the question of whether the government (and, ultimately, the population) of this country ought to bear the costs of the country's earlier decision to borrow-or whether these costs ought to be pushed (in part or as a whole) onto others.

\section{Principles of Cost Allocation}

What principles would we appeal to in determining who is responsible for the costs in the case just imagined? The answer to this question has seemed plainly obvious to some advocates of human rights and poverty relief. They deny that we can reasonably demand that a country repay its debts or fulfil other contractual obligations when repayment will predictably lead to deprivations for its population, especially since others (such as wealthy countries or financial institutions) could arguably bear the financial costs of nonrepayment of these debts in a way that would not lead to comparably regrettable outcomes. The Austrian economist Kunibert Raffer has argued, for example, that 'one must not be forced to fulfill contracts if that leads to inhumane distress, endangers one's life or health, or violates human dignity. Civilized laws give unconditional preference to human rights and human dignity.' ${ }^{19}$ This view is endorsed by many others, including advocates of the Fair and Transparent Arbitration Process (FTAP), developed by Raffer and modelled on chapter 9 of the US Bankruptcy Code, which governs the bankruptcy of municipalities. The FTAP would ensure that the basic human rights (somehow understood) of citizens of debtor countries are given higher priority than creditors' rights in the management of debt crises. ${ }^{20}$ Those who favour such initiatives appeal to what David Miller aptly calls the capacity principle, which requires that those who can alleviate acute deprivations most easily must do so regardless of their connection to them. ${ }^{21}$

On this view, those with access to funds ought to spend them in ways to help those at most risk of suffering severe deprivation. Such actors need not be governments: the head of the UN Conference on Trade and Development recently called on the IMF to provide debt relief to developing countries that have diminished foreign reserves due to the crisis. ${ }^{22}$ The IMF in fact responded by reducing interest rates to zero until 2011 for some of its loans. The Fund is financing this move by selling off some of its substantial gold reserves. ${ }^{23}$ Were those with the greatest capacity to avert severe deprivation to do so, one would expect much more aggressive measures by wealthy countries. The thought is not that market participants should not generally bear the risks of their decisions-no market

\footnotetext{
${ }^{19}$ K Raffer, 'Risks of Lending and Liability of Lenders' (2006) 21(1) Ethics \& International Affairs 93.

${ }^{20}$ See, eg Erlassjahr, 'A Fair and Transparent Arbitration Process for Indebted Southern Countries', updated submission to Financing for Development, September 2001, available at www.erlassjahr.de/content/languages/ englisch/dokumente/ftap_englisch_rz.pdf (accessed on 26 August 2009).

${ }^{21}$ D Miller, 'Distributing Responsibilities' (2001) 9(4) Journal of Political Philosophy 453.

22 'Poor Nations Need Temporary Debt Relief Amid Economic Crisis-Senior UN Official'. UN News Service, 30 April 2009, available at http://www.un.org/apps/news/story.asp?NewsID $=30643 \& C r=F i n a n c i a l \& C r 1=$ crisis (accessed on 26 August 2009).

${ }_{23}$ 'IMF Backs New Package to Support World's Poorest During Crisis', IMF Survey, 29 July 2009, available at http://www.imf.org/external/pubs/ft/survey/so/2009/POL072909A.htm (accessed on 26 August 2009).
} 
system could function well without doing this-but that certain extremely bad outcomes should not be allowed to stand when they can be averted at relatively small cost.

The capacity principle holds that the provision of assistance should depend on how heavily burdened the population of a country would be in absolute and relative terms were that country to pay its debts or absorb the full burden of its financial losses and how costly it would be for others to offset the costs that it would otherwise face. It might plausibly be argued, however, that whichever claims take precedence ought to depend not only on this, but also upon how the country became heavily indebted, or economically vulnerable, in the first place. Miller himself, for example, has recently argued that 'If people have poor or otherwise inadequate lives because of decisions or actions for which they are responsible, then outsiders have no obligation of justice to intervene.'24 There, we would justify departures from the capacity-based allocation of costs by appeal to what might be called the principle of contributory fault.

The principle of contributory fault sharply limits the conditions under which those who suffer hardships can disrupt others' plans and shift the costs of alleviating their deprivations onto those third parties. It is worth pausing to explore this principle and to examine its possible application to different agents involved in sovereign borrowing and lending. Drawing on the car accident analogy, we can look to tort law for guidance. Standards of tort liability generally demand that an agent bear the costs of her harmful conduct when it can be shown that:

1. she has causally contributed to them;

2. the harmful outcome was her fault; and

3. the faulty aspect of her conduct (and not merely her conduct as a whole) was causally relevant to the outcome (for example, to show that some driver is liable for the injuries of another person, it must not merely be shown that the driver was negligent and that she caused the accident, but that the injuries resulted from her negligence). ${ }^{25}$

Theorists of the law of torts differ over how these conditions should be understood, but there are some elements that are common to nearly all accounts of them. First, the notion of fault operates with some notion of a 'standard of care'. That is, agents are at fault for some harmful outcome, and thus can be held liable for bearing its cost, when they have not lived up to an objectively defined normative standard. ${ }^{26}$ When an agent fails to live up to this standard, she is deemed to be 'negligent', and thus at fault for any harmful outcome of her conduct. Secondly, the normative standard that is invoked for the purpose of determining negligence depends on some conception of what a 'reasonable person' could be expected to have done in the situation given what was foreseeable in the context in which the agent acted. If the agent acted in the way a reasonable person could have been expected to act in the circumstances, then that agent did not act negligently and is thus not at fault for the costs engendered by her conduct. Consequently, such an agent should not be made to bear these costs, even if her conduct is causally relevant to bringing them about. If,

\footnotetext{
${ }^{24}$ D Miller, 'Justice and Global Inequality' in A Hurrell and N Woods (eds), Inequality, Globalization and World Politics (Oxford, Oxford University Press, 1999) 187-210.

${ }_{25}$ For a discussion, see RW Wright, 'The Grounds and Extent of Legal Responsibility,' (2003) 40 San Diego Law Review, available at SSRN: http://ssrn.com/abstract $=438640$.

${ }^{26}$ These notions are described well in A Ripstein, Equality, Responsibility, and the Law (Cambridge, Cambridge University Press, 1999).
} 
when driving at normal speeds and obeying all traffic signals, I swerve my car to avoid hitting a child dashing across the street and smash into a parked car, I am not at fault for the damage done to the parked car, and thus not liable in tort for bearing the costs of its repairs.

The contributory fault principle might also be thought to apply to countries. ${ }^{27}$ If a country has acted negligently, either through severe imprudence or recklessness, it might therefore be argued that the costs resulting from this cannot fairly be pushed onto others, no matter how severe they may be, even if the country can now shoulder these costs only with great difficulty and at significant sacrifice. To be plausible, this type of argument would require a compelling account of how a standard of care can be defined to apply to collective agents like countries-and this, in turn, will depend on a convincing account of what a reasonable country would do under various sets of circumstances.

However challenging it may be to develop a plausible conception of the contributory fault principle for countries, some principle of this kind is likely to hold quite significant intuitive appeal, not least because failing to hold countries responsible for their irresponsible conduct may provide very poor incentives for the future. It is also difficult to deny that some of the damages of the current crisis have resulted from countries' failures to exercise reasonable care in the management of their financial affairs. For instance, under General Pervez Musharraf Pakistan borrowed heavily and spent its foreign reserves on imports, only to find itself unable to repay its debts as its currency collapsed last autumn. ${ }^{28}$ The same pattern of excessive borrowing and inability to repay is visible in a number of other developing and emerging economies, including Ukraine, where paralysing political infighting has prevented economic reform for years, and Latvia, which directed foreign capital toward now much diminished real estate and mortgage lending. ${ }^{29}$ All three-among others- have turned to the IMF for emergency loans to cover their foreign obligations.

It seems extremely unlikely, however, that any conception of the contributory fault principle would provide grounds for concluding that the burdens resulting from the financial crisis more generally should be borne solely or even mostly by the populations of the poorer countries. This is so for several reasons. First, a great deal of the damage resulting from this crisis cannot plausibly be characterised as resulting from the imprudence or recklessness of poorer countries. The unstable global environment in which they operate produces many changes to the circumstances of these countries; these changes are not only impossible for them to control, but also quite difficult or impossible to foresee. ${ }^{30}$ The present financial crisis is only the most recent and vivid example of such instability.

In response to this, it may be argued that these are simply the risks of activities like borrowing money and other economic activities. That is, while specific circumstances are

\footnotetext{
${ }^{27}$ Miller's own view on how such an idea might be extended to nations: see D Miller, 'National Responsibility and International Justice' in D Chatterjee (ed), The Ethics of Assistance: Morality and the Distant Needy (Cambridge, Cambridge University Press, 2004).

${ }^{28}$ S Mufti, 'Cash-strapped Pakistan Finds Few Friends in Time of Economic Need', Christian Science Monitor, 23 October 2008, available at http:// www.csmonitor.com/2008/1023/p04s01-wosc.html.

${ }^{29}$ D Stern, 'Economic Crisis Sweeps Eastern Ukraine' (8 April 2009), available at http:// www.nytimes.com/2009/04/08/world/europe/08ukraine.html (accessed on 26 August 2009); O Ryan, "Latvia's Dramatic Fall from Grace," BBC News, 8 June 2009, available at http://news.bbc.co.uk/go/pr/fr/-/2/hi/ business/8085007.stm (accessed on 26 August 2009).

${ }^{30}$ For an illuminating discussion by a policymaker about why so few foresaw the crisis, see D Gruen, 'Reflections on the Global Financial Crisis', Keynote Address at the Sydney Institute, 19 June 2009, available at http://www.treasury.gov.au/documents/1564/PDF/Sydney_Institute_Address.pdf (accessed on 26 August 2009).
} 
impossible to foresee, any borrower is aware (or at least should be aware) that there are general risks that accompany economic activities like borrowing money, which include the risks of financial crises and natural disasters. It is a common feature of contracts that those who engage in them are usually supposed to assume the risk that fulfilling the conduct that is required of them will turn out to be more difficult, and perhaps much more difficult, than anticipated. ${ }^{31}$ Critically, however, the law also acknowledges that there are contexts in which this supposition no longer holds. For example, if an unanticipated tsunami of unprecedented ferocity wreaks havoc on some country's economy, this event should not be viewed as part of the 'normal' background risks that agents ought to have considered when entering into contracts or in making other financial decisions. Indeed, contract law and the law of torts has made legally relevant the distinction between ordinary and extraordinary events that lead to the non-performance of contracts or damages. When extraordinary events-including so-called acts of god-lead to nonperformance of contracts, the duty to perform them is excused in many legal systems and the contract is viewed as 'impracticable. ${ }^{32}$ When the performance of a contract becomes impossible for reasons other than the negligence of the contracting parties, it is typically treated as void under the doctrine of frustration. ${ }^{33}$

This analysis suggests that there are some respects in which the financial crisis was like a tsunami after all. Although made-made-the critical difference - the financial crisis was (with a few exceptions) unforeseen, and, from the perspective of under-resourced developing countries, unpredictable. ${ }^{34}$ For policymakers in developing countries, the collapse of Lehman Brothers and its consequences for financial markets, for example, would have been very similar to the deadly tsunami of 26 December 2004. Without a warning system in place, few would have known that the damage was occurring until much of it was already irreversible.

In addition, in those cases where countries have clearly conducted themselves irresponsibly, it often does not seem plausible that the vast majority of their present and future people should bear the full cost of this conduct. There are several reasons for this. First, on any plausible reading of the contributory fault principle, it will not follow from the mere fact that some agent's negligence or misconduct has been a cause of some harm that he should bear the full cost of that harm. This is especially true when the negligence or misconduct of other agents were also causes of it. Imagine that a pedestrian crosses a busy street against a red light without paying attention to the passing cars, and is hit by a driver who does not see the pedestrian because the driver is talking on his cell phone. In this scenario, most modern law will allocate the liability for the pedestrian's injuries between

\footnotetext{
${ }^{31}$ See PS Atiyah, Introduction to the Law of Contract, 5th edn (Oxford, Oxford University Press, 1995), esp $212-15$, for discussion.

32 The US Uniform Commercial Code, $\$ 2-615$, for example, excuses a party from delivering goods specified in a contract when the reason for their failure to do so results from events such as 'acts of god', whose absence was a 'basic assumption' of the contract, whether or not such exclusion is specifically stated in the contract. For detailed discussion of the jurisprudence and justification of these measures, see AO Sykes, 'The Doctrine of Commercial Impracticability in a Second-Best World' (1990) 19(1) Journal of Legal Studies 43; RA Posner and AM Rosenfield, 'Impossibility and Related Doctrines in Contract Law: An Economic Analysis' (1977) 6(1) Journal of Legal Studies 83.

${ }^{33}$ For a discussion see Atiyah, above n 31, 229-44.

${ }^{34}$ Tellingly, the NYU economist Nouriel Roubini, now famous for having predicted the crisis, was profiled dismissively by Prakash Lougani in the IMF's in-house newsletter in 2006 under the headline 'Meet Dr Doom' (IMF Survey, 16 October 2006, 308, available at www.imf.org/external/pubs/ft/survey/2006/101606.pdf (accessed on 26 August 2009)).
} 
the driver and the pedestrian to the extent of their fault. This seems reasonable-why, after all, should the cost that results from the negligence of one actor be borne entirely by someone else, even when this second person has also acted negligently?

This consideration may be particularly relevant when there is a clear connection between the negligence of one actor and another, such that the negligence of one agent can plausibly be viewed as encouraging (and thus significantly raising the risk of) negligent conduct by the other. If we lend a car to our teenage niece and she drives it into a tree after drinking several cocktails, then she has clearly acted negligently and can reasonably be expected to bear at least some of the cost of the harms her conduct creates. The extent to which she should bear the cost of harms, however, will also depend on other factors, such as whether her acquiring the alcohol involved the negligence of other actors. If a liquor store clerk served her without requesting proper identification, then this clerk (and perhaps also his employer) can be held partially liable for the costs of the accident. And if we have acted negligently by buying liquor for her, it can reasonably be questioned whether we retain any claim whatsoever to compensation for the damages to our car that ensue from her conduct, or, indeed, whether we should escape from full liability for the harms her conduct inflicts on others.

These considerations are particularly relevant in the context of assessing responsibility for the costs to poorer countries that are the result of the present financial crisis. While the negligence of poorer countries may have played some role in creating these costs, the negligent conduct of other countries seems also to have contributed causally to them. Indeed, regulators in the US and the UK have admitted as much. In March 2009, Verena Ross, director of strategy and risk at the UK's Financial Services Authority (FSA), laid blame at the feet of the FSA and other major regulators for a 'failure to identify that the whole system was subject to market-wide, systemic risk. ${ }^{35}$ In the US, chairman of the Security and Exchange Commission (SEC) Christopher Cox-while resisting broad claims of responsibility-acknowledged that the SEC's programme to regulate Wall Street investment banks was 'fundamentally flawed from the beginning', a failure which in turn contributed to the financial crisis. ${ }^{36}$ The SEC seems to have been particularly negligent as a regulator. Under the Bush administration, the SEC was 'missing in action' and simply failed to regulate according to its mandate, not to mention its failure to act when tipped off to Bernard Madoff's Ponzi scheme. ${ }^{37}$ The US Federal Reserve has also been a focal point of criticism. Its formerly unimpeachable ex-chairman, Alan Greenspan, admitted in a Congressional hearing that his deregulatory ideology was flawed and had contributed to the current crisis. ${ }^{38}$ Many critics, such as economist Jeffrey Sachs, go further, arguing that

\footnotetext{
${ }^{35}$ V Ross, 'Lessons from the Financial Crisis', speech to the Chatham House conference on Global Financial Regulation, London, 24 March 2009, available at http://www.fsa.gov.uk/pages/Library/Communication/ Speeches/2009/0324_vr.shtml (accessed on 26 August 2009).

${ }^{36}$ S Labaton, 'SEC Concedes Oversight Flaws Fueled Collapse', New York Times, 27 September 2009, available at http://www.nytimes.com/2008/09/27/business/27sec.html.

${ }^{37} \mathrm{~J}$ Westbrook and R Schmidt, 'Cox "Asleep at Switch" as Paulson, Bernanke Encroach,' Bloomberg, 22 September 2008, http://www.bloomberg.com/apps/news?pid=20601109\&sid=aoM0mju1ARQo\&refer=home (accessed on 26 August 2009); A Blumberg, 'Now You SEC Me, Now You Don't', This American Life, 12 September 2008, available at http://www.thisamericanlife.org/Radio_Episode.aspx?sched=1260; J Westbrook, D Scheer and M Pittman, 'Madoff Tipster Markopolos Cites SEC's "Ineptitude", Bloomberg, 4 February 2009, available at http://www.bloomberg.com/apps/news?pid=20601103\&sid=axvJfch6PDjs\& (accessed on 26 August 2009).

${ }^{38} \mathrm{~K}$ Scannell and S Reddy, 'Greenspan Admits Errors to Hostile House Panel', Wall Street Journal, 24 October 2008, available at http://online.wsj.com/article/SB122476545437862295.html?mod=todays_us_page_one (accessed on 26 August 2009).
} 
Greenspan's decision to keep US interests rates low after 9/11 recklessly encouraged the kind of excessive borrowing that Pakistan, Ukraine and many other countries engaged in. ${ }^{39}$

Furthermore, the widespread official practice of guaranteeing the 'political risk' faced by lenders-the promise to the lender by its government that the latter will bail out the former and take over its claims in case the debtor government declines for whatever reason to honour an obligation - creates a double moral hazard in the international lending system. On the one hand, more capital will flow to reckless governments, which will tend to be willing to borrow more than would be prudent from the standpoint of their population; on the other hand, since creditors will have incentives to lend more, the greater their exposure, the greater the likelihood their government will need to bail them out in order to prevent losses to domestic stockholders. This practice shifts a great deal of the risk to the population of the borrower government, which will have to repay or otherwise make other concessions to the government of the lender. For example, in the 1970s US private banks lent to Indonesia's national oil company Pertamina, even as the US Senate Committee on Foreign Relations declared that the company's debt was uncontrollable and the IMF had put a cap on the loans that should be made available to the country. Nevertheless banks lent above the IMF ceiling and, when the crisis broke out, the US government stepped in to bail them out and assumed Indonesia's obligations. ${ }^{40}$ It hardly needs mentioning that the same kind of moral hazard is at work in the numerous corporate bailouts enacted by affluent governments. ${ }^{41}$ The current system is not one in which all market participants are expected to bear the risks of their choices.

In practice, debtor countries are often in so vulnerable a condition that refraining from entering into debt contracts with creditors (even particular creditors) is not a reasonable option for them. Faced with the choice of making a loan that it knows will be difficult to repay and forgoing funds needed to maintain basic services and governmental functions, it seems likely that any reasonable government would borrow. In domestic legal contexts of this kind, contracts are often viewed as non-binding, either because they were entered into under severe duress or because enforcing them would be unconscionable. ${ }^{42}$

Even when (unlike in this case) it seems appropriate to attribute the costs of crises entirely or mainly to the negligent conduct of a country, it may be implausible to hold the vast majority of the country's present and future people solely, mainly and, in some cases, even partially responsible for shouldering the costs that such crises engender, especially with respect to severe deprivation. One main reason for this relates to the fact that those

\footnotetext{
${ }^{39}$ J Sachs, 'The Roots of Crisis', The Guardian, 21 March 2008, available at http://www.guardian.co.uk/ commentisfree/2008/mar/21/therootsofcrisis (accessed on 26 August 2009). For an insightful overview of the relationship between low interests rates and the financial crisis, see 'The Giant Pool of Money', This American Life, 9 May 2008, available at http://www.thislife.org/radio_episode.aspx?episode=355 (accessed on 26 August 2009).

${ }^{40}$ For a discussion of this example and the (in)operation of risk in international lending, see K Raffer, 'Risk of Lending and Liability of Lenders' (2007) 21(1) Ethics and International Affairs 85. For a more extended discussion of the various ways that the international lending system encourages problematic borrowing and lending, see C Barry and L Tomitova, 'Fairness in Sovereign Debt' (2006) Social Research 74.

${ }^{41}$ For details of US bailouts, see 'History of US Bailouts', Pro Publica, 15 April 2009, available at http://www.propublica.org/special/government-bailouts; 'Adding Up the Government's Total Bailout Tab', New York Times, 4 February 2009, available at http://www.nytimes.com/interactive/2009/02/04/business/ 20090205-bailout-totals-graphic.html (accessed on 26 August 2009).

${ }^{42}$ It is worth noting that the domestic law of many countries has traditionally regarded with great suspicion loans to poor persons in distress, such as by payday lenders or check cashers. For discussion see J Cartwright, Unequal Bargaining: A Study of Vitiating Factors in the Formation of Contracts (Oxford, Clarendon Press, 1991).
} 
agents who take out a loan or make financial decisions and those who are obliged to repay it are different. It is the finance ministers and other public officials of a country's government who make borrowing decisions in the name of the country, while it is the present and future citizens and other subjects taxable by the government who are asked to do the repaying. Of course, this is not in itself necessarily problematic. Indeed, when a creditor's claims on individual agents, for example, result from decisions or policies that have been adopted by the agent's political community, and where she either played some role in choosing the policy or at least had her interests given adequate weight by those making the decision, there is at least a prima facie case for taking her to be obliged to honour them. ${ }^{43}$ The present and/or past governments of many vulnerable countries, however, are not even minimally representative of the interests of those they rule, failing to give due consideration to the interests of its people in both the making of decisions and in the decisions themselves.

\section{Determining Responsibility in the Real World}

In the real world, it is often difficult, if not impossible, to determine with much con?dence whether and to what extent different individual and collective agents (a person, a development bank, a firm, a national government, and so on) have individually and collectively contributed through their negligent conduct to severe deprivations. It is thus unclear whether those who grant substantial weight to the principle of contributory fault should take these agents to have responsibilities to remedy them, or how weighty they ought to hold them to be. This problem can only be fruitfully addressed by examining the appropriateness of different standards - which we call standards of application - that might be appealed to for determining agents' responsibilities in such contexts. ${ }^{44}$ Let us imagine the following case: a relatively poor developing country (DC), asserts that a rich country (RC) has undertaken a set of policies $(\mathrm{P})$ that have contributed to severe deprivations among DC's citizens.

Because of this, DC argues, RC has strong contributory-fault-based reasons to undertake efforts to alleviate these problems and to avert further deprivations that RC's past conduct would otherwise cause in the future. Evaluating DC's compensation claim in contexts in which substantial factual uncertainties of this kind are present will require us to distinguish three different standards of application for the contributory fault principle:

1. The burden of proof: who has the burden of proof in this case? Must DC (or some other agent) show that $\mathrm{P}$ contributed to the deprivations in question? Or must RC show that it has not done so?

2. The standard of proof: what evidential threshold must be reached for it to count as proven that $\mathrm{P}$ did or did not contribute to deprivations amongst DC's people?

\footnotetext{
${ }^{43}$ As argued in D Miller, National Responsibility and International Justice (Oxford, Oxford University Press, 2007).

${ }^{44}$ This section draws on discussions of these themes in C Barry, 'Understanding and Evaluating the Contribution Principle' in A Follesdall and T Pogge (eds), Real World Justice (Dordrecht, Kluwer, 2005) 103-37 and 'Applying the Contribution Principle' (2005) 36(1-2) Metaphilosophy 210.
} 
3. The constraints on admissible evidence: what kinds of evidence may be employed to corroborate the thesis that $\mathrm{P}$ has contributed to deprivations amongst DC's people?

How each of the standards of application identified above is specified will often be quite consequential. But how can we determine whether any particular way of specifying these standards is fair? The first thing to note is that there is no obviously correct answer to this question, nor is there any neutral or natural way of specifying these standards that can serve as a default. It clearly depends upon the context of the inquiry and the goals of the practice within which it is undertaken. For example, the appropriateness of different standards of application for establishing a causal connection between some chemical substance and a medical condition may vary, depending upon whether we are engaged in scientific inquiry, criminal or civil legal proceedings, or ethical reflection. Consider some agent $\mathrm{A}$, who operates a factory that is alleged to release chemical agents that are harmful to children. In a criminal trial in which A is accused of causing serious health problems to children in a neighbouring school, most would insist that high evidential thresholds be employed for determining the causal links between the substance and the harm, and that the burden of proof be placed with the prosecution. We might further insist on very strict constraints on admissible evidence, perhaps allowing only epidemiological studies conducted using methodologies sanctioned by highly regarded professionals to count as evidence of causation. We might also demand only what Judith Thomson has called 'individualized' evidence, which is 'in an appropriate way causally connected with the (putative) fact that the defendant caused the harm', rather than 'probabilistic' evidence that the chemical was causally relevant to the harm. ${ }^{45}$

In a civil trial in which some agent $\mathrm{A}$ is being tried for a similar offence, however, establishing a 'preponderance of evidence'-that is, it is more likely than not-that the chemical released by A has contributed to the children's health problems might provide adequate grounds for assigning liability to him. We might also allow a broader range of evidence (such as studies of the effects of the chemical on animals), or merely probabilistic evidence. If the question is whether further such chemical releases should be legally permitted, it is not implausible that even slight evidence that these releases harm children should suffice to disallow them, at least until further study of their effects can be undertaken. ${ }^{46}$

When we engage in ethical reflection about what the correct policy response should be, meanwhile, the mere suspicion that one may have contributed to some acute deprivation often provides sufficient reason to act to address it. If, for example, A suspects that the chemical she has released may have contributed to children's health problems, she might reasonably take herself to have an ethical responsibility (although not a legal or enforceable one) to contribute towards meeting the costs of the treatment of their problems - or at least more reason to do so than she would have in the absence of her suspicion that she may have contributed to their condition. This may also be true where it is impossible to determine whether the preponderance standard is met, or even when we know that it has not been met.

${ }^{45}$ J Thomson, 'Liability and individualized evidence' (1986) 49(3) Law and Contemporary Problems 199, 203.

${ }^{46}$ For a discussion of the standards relevant for determining the toxicity of substances in basic scientific research and governmental regulation see C Cranor, Regulating Toxic Substances: A Philosophy of Science and the Law (New York, Oxford University Press, 2007). 
Different standards of application will result in different probabilities of these types of errors. In characterising any such set of standards, then, some view must be taken of the relative costs of these types of errors. Stringent standards of proof and restrictions on admissible evidence in criminal proceedings, for example, re?ect a strong aversion to Type 1 errors ${ }^{47}$ expressing the conviction that falsely criminalising the innocent is more costly than allowing many crimes to go unpunished. The preponderance standard in civil procedures also expresses an aversion to Type 1 errors, re? ecting a willingness to err on the side of failing to allocate resources to those who have been injured by inordinately risky conduct or products. However, it is much less stringent than the standard of application for criminal trials, and it foreseeably engenders both a higher probability of Type 1 errors and a lower probability of Type 2 errors.

Returning to our imagined case, if we believe that the cost of Type 1 errors to RC is substantially less than the potential cost of Type 2 errors to DC, for example, then we ought strongly to consider adopting standards of application that are far more tolerant of Type 1 than of Type 2 errors in assessing claims of contributory fault, and vice versa.

But what are the relative costs of Type 1 and Type 2 errors in the case of RC and DC? Consider first the cost of a Type 1 error to respondents such as RC if the claim of contributory fault is falsely found to be true. This cost will depend on how well off RC is, how badly off the claimants are (for example, the deprived parties in DC) and how much it will cost for RC to alleviate their deprivations. These costs may be monetary, involving the transfer of resources, but they might also involve the extension of special privileges and rights to DC, such as tariff-free access to RC's markets, or perhaps RC's efforts to increase the quantity of funds available to DC at lower rates of interest. In practice, these costs seem manageable. If, for instance, the US wrongly assumed that it had harmed some group of developing countries and gave away $0.7 \%$ of its stimulus package- as proposed by the president of the World Bank-it would have lost only some $\$ 4.9$ billion. ${ }^{48}$ That is the cost of about 11 days of war in Iraq, or about 3\% of the American International Group (AIG) bailout. ${ }^{49}$

But what of the costs of Type 2 errors to the subjects that might wrongfully go uncompensated-in this case, the deprived parties in DC? Since, by hypothesis, DC is a poor country, those who suffer from severe deprivations within its territory will likely remain very badly off if they do not receive the funds. This, of course, depends on the assumption that the world that RC and DC inhabit is one like our own, and does not possess formal mechanisms (such as a global system of social insurance) or informal arrangements (such as a generally known and complied-with norm of providing assistance to the severely deprived) that reliably meet the costs of addressing severe deprivations within DC. (Recall that we should expect per capita income in sub-Saharan Africa to decline by one-fifth this year.)

Given the relative costs to RC and DC of Type 1 and Type 2 errors, we conclude that there is a strong prima facie case for specifying standards of application for applying the

\footnotetext{
${ }^{47}$ For an explanation of type 1 and type 2 errors see http://www.stats.gla.ac.uk/steps/glossary/hypothesis_ testing.html (accessed on 26 August 2009).

${ }^{48} \mathrm{R}$ Zoellick, 'A Stimulus Package for the World', New York Times, 22 January 2009, available at http://www.nytimes.com/2009/01/23/opinion/23zoellick.html (accessed on 26 August 2009).

${ }_{49}$ D Goldman, "Iraq War Could Cost Taxpayers \$2.7 Trillion," CNNMoney, 12 June 2008, available at http://money.cnn.com/2008/06/11/news/economy/iraq_war_hearing/index.htm (accessed on 26 August 2009); 'American International Group, Inc', New York Times, 13 May 2009, available at http://topics.nytimes.com/ top/news/business/companies/american_international_group/index.html (accessed on 26 August 2009).
} 
principle of contribution that expresses a willingness to err in favour of the severely deprived subjects, whether they are the party alleging that they have been harmed or the party against which such claims have been made. In other writings, ${ }^{50}$ one of us has called this norm the 'vulnerability presumption principle'. While implausible as a principle for specifying standards of application in a criminal legal context (and most likely in most civil legal contexts), or as a principle for assessing ethical responsibilities more generally, the vulnerability presumption principle seems clearly superior to stringent standards of proof and evidence with respect to the determination of ethical responsibilities to address severe deprivations.

\section{E. Conclusion: Implications for Policy Orientation}

The international response to the financial crisis's devastating effects on developing countries has been extremely limited so far. There has been no global stimulus, despite calls from the UN and the IMF, nor has there been a great outpouring of development aid-perhaps more aptly termed humanitarian aid in this case. The meeting of the Group of 20 in April was trumpeted as good news for the poor, but resulted only in increased funding for IMF loans. Some countries have balked at the application of traditional IMF conditionality to these loans. Ukraine, for instance, argued that it would have had to reduce social spending in order to be eligible for additional IMF funding. While a detailed analysis of the human impacts of IMF conditionality is beyond the scope of this chapter, our analysis above gives us some reason to question this method-conditional IMF loans-as a means for responding to the crisis.

Although there would not be enough evidence to hold Alan Greenspan and other regulators responsible in a criminal—or even civil—court for the harm their policies have caused to developing countries (along with the damages caused to their own and other developed countries, of course), as we have argued, the standards here are different. When the livelihoods of the world's poorest people are at stake, as they are here, we ought to construct standards that err in their favour. We suggest that any plausible specification of those standards would hold the world's financial giants, especially the US and UK, morally liable for contributing to harm in the developing world. The admissions of guilt by key regulators reviewed above indicate as much. As such, these countries have contributory fault-based duties to ameliorate the damage done, and to ensure that they will not cause further harm in the future. Simply increasing the indebtedness of developing countries would not discharge these duties.

What would a more appropriate policy response look like? To start, governments that are implementing fiscal stimulus should consider designing their policies so that they advantage rather than disadvantage developing countries. This guideline would lead not only to disallowing provisions like the notorious "Buy American" clause in the US stimulus package, it could also lead policymakers to consider supporting domestic industries that have strong connections with other countries. For instance, the decline in the US

\footnotetext{
50 Barry, above n 44.
} 
construction industry has led to a decrease in remittances to Latin American countries, whose emigrants often man construction sites. ${ }^{51}$

In addition, affluent governments should give no-strings-attached development aid, in the form of grants rather than loans where possible, insofar as it seems likely that doing so would benefit the recipient populations. ${ }^{52}$

Consider that the US government has given $\$ 150$ billion in loans to the thoroughly discredited AIG and $\$ 97$ billion to the US auto industry. ${ }^{53}$ It is extremely unlikely that these loans will be recouped in full. In contrast, all developed countries combined gave a total of $\$ 12.2$ billion in aid for basic social services in 2007 , the last year for which data is available. ${ }^{54}$ Assisting developing countries in balancing the budgets that the affluent have broken would be cheap in comparison. To return to our analogy, the world's affluent governments are currently speeding away from the scene of an accident. It is not too late for them to turn around and help to offset the costs of this accident for those least able to bear them.

${ }^{51}$ D Ratha, S Mohapatra and A Silwal, 'Outlook for Remittance Flows 2009-2011: Remittances Expected to Fall By 7-10 Percent in 2009', Migration and Development Brief 10 (World Bank, 13 July 2009), available at http://siteresources.worldbank.org/INTPROSPECTS/Resources/334934-1110315015165/Migration\&Developme ntBrief10.pdf (accessed on 26 August 2009).

${ }_{52}$ Injecting more resources into a very poorly governed society or one with a corrupt government would not, obviously, meet this requirement.

53 'American International Group', above n 46; J Hyde, 'Bottom Line: US Auto Industry Says It needs $\$ 97.4$ Billion to Live', Detroit Free Press, 19 February 2009, available at http://www.freep.com/article/20090219 /BUSINESS01/902190486/1210/BUSINESS/Bottom+line++US+auto+industry+says+it+needs+\$97.4+billion+t o+live (accessed on 26 August 2009).

${ }^{54}$ United Nations, 'Millennium Development Goals Indicators, 2009', available at http://unstats.un.org/unsd/ mdg/Data.aspx (accessed on 23 July 2009). 